\title{
IMPLEMENTASI IDE RESTORATIVE JUSTICE KE DALAM KETENTUAN PERATURAN PERUNDANG-UNDANGAN ANAK DI INDONESIA
}

\author{
Boyce Alvhan Clifford, Barda Nawawi Arief \\ Magister Ilmu Hukum, Universitas Diponegoro \\ Email : alvhanr@gmail.com
}

\begin{abstract}
ABSTRAK
Restorative Justice merupakan penyelesaian perkara tindak pidana dengan melibatkan pelaku, korban, keluarga pelaku/korban, dan pihak lain yang terkait untuk bersama-sama mencari penyelesaian yang adil dengan menekankan pemulihan kembali pada keadaan semula, dan bukan pembalasan. Restorative Justice sebenarnya memiliki posisi yang strategis sebagai suatu sarana dalam mempertahankan hak-hak anak yang berkonflik dengan hukum. Namun yang menjadi kendala adalah bagaimana Restorative Justice itu tidak dapat berjalan secara efisien bila diterapkan bukan dengan cara yang benar. Penelitian ini dilakukan bertujuan untuk mengetahui sinkronisasi/harmonisasi formulasi ide Restorative Justice di berbagai peraturan perundang-undangan anak di Indonesia, baik yang berlaku sekarang ini (ius constitutum) maupun di masa mendatang (ius constituendum). Dengan menggunakan metode Yuridis Normatif dalam arti luas, penelitian ini tidak hanya sebatas melihat secara logis/ sistematis dalam keseluruhan perangkat norma melainkan juga mencakup latar belakang filosofis, sosiologis, historis, komparatif, dari implementasi ide restorative justice itu sendiri. Tidak sebatas implementasi dalam formulasi ketentuan peraturan perundang-undangan saja, bagaimana ketentuanketentuan tersebut dilaksanakan dalam masyarakat juga perlu diperhatikan dalam mencapai suatu keadilan restoratif bagi anak.
\end{abstract}

Kata Kunci:Restorative Justice, Formulasi, Peraturan perundang-undangan, Anak

\begin{abstract}
Restorative Justice is a settlement of criminal cases involving perpetrators, victims, families of perpetrators / victims, and other concerned parties to jointly seek a fair settlement by emphasizing restoration back to its original state, rather than retaliation. Restorative Justice actually has a strategic position as a means of defending the rights of children in conflict with the law. But the constraint is how Restorative Justice can not run efficiently if applied not in the right way. The aim of this research is to find out the synchronization / harmonization of Restorative Justice idea formulation in various laws of child in Indonesia, both current (ius constitutum) and in the future (ius constituendum). By using the Normative Juridical method in a broad sense, this research is not only limited to looking logically / systematically in the whole set of norms but also includes the philosophical, sociological, historical, and comparative background of the implementation of the idea of restorative justice itself. Not only the implementation of the formulation of the provisions of legislation only, how the provisions are implemented in the community also need to be considered in achieving a restorative justice for children.
\end{abstract}

Keywords: Restorative Justice, Formulation, Regulation of Legislation, Children.

\section{PENDAHULUAN}

Anak sebagai bagian dari generasi muda merupakan penerus cita-cita perjuangan bangsa dan merupakan sumber daya manusia bagi pembangunan nasional ke depan. ${ }^{1}$ Mereka sebagai tunas, potensi, dan generasi muda penerus bangsa harus diasuh, dilindungi, dan dididik dengan baik. Setiap anak berhak atas kelangsungan hidup, tumbuh dan berkembang serta berhak atas perlindungan dari kekerasan dan diskriminasi sebagaimana diamanatkan dalam Undang-Undang Dasar Negara Republik Indonesia Tahun 1945. Dalam kehidupan manusia sebagai makhluk bermasyarakat,

\footnotetext{
${ }^{1}$ Ediwarman, Peradilan Anak di Persimpangan Jalan dalam Prespektif Victimology (belajar dari kasus Raju), Vol.18 No. 1, April 2006, Jurnal Mahkamah, Pekan baru, 2006, hal.8.
} 
eksistensi anak merupakan bagian dari masyarakat yang mempunyai posisi yang sangat rentan dari berbagai kondisi karena ketidakberdayaannya dalam berbagai hal, dan masih tergantung pada orang lain, lebih tepatnya orang dewasa.

Kenyataan yang terlihat sekarang ini banyak dari mereka tidak lagi mendapatkan apa yang seharusnya mereka dapatkan untuk menunjang perkembangannya menjadi generasi penerus. Banyak hak-hak anak yang tidak lagi dipenuhi dan sebagian dari mereka tidak lagi merasakan kebahagian yang seharusnya dirasakan seorang anak. Salah satu upaya perlindungan anak yang diberikan oleh pemerintah adalah diwujudkannya ide Restorative Justice ke dalam formulasi ketentuan peraturan perundang-undangan di Indonesia seperti yang terdapat pada Undang-undang No.11 tahun 2012 tentang Sistem Peradilan Pidana Anak.

Keadilan restoratif (Restorative Justice) adalah bentuk keadilan yang berpusat pada kebutuhan korban, pelaku kejahatan, dan masyarakat. Berbeda dengan keadilan retributif yang menekankan hukuman bagi pelaku kejahatan, keadilan restoratif mementingkan pemulihan korban, pelaku kejahatan, dan masyarakat. ${ }^{2}$ Jim Consedline seorang pelopor keadilan Restoratif, berpendapat "konsep keadilan retributif dan restitutif yang berlandaskan hukuman, balas dendam terhadap pelaku, pengasingan, dan perusakan harus digantikan oleh Keadilan Restoratif yang berlandaskan rekonsiliasi, pemulihan korban, integrasi dalam masyarakat, pemaafan, dan pengampunan. ${ }^{3}$

Berkaitan dengan harapan pemulihan (restorasi) di atas, keadilan restoratif fokus kepada kebutuhan tiga pihak, yaitu korban, pelaku kejahatan, dan masyarakat, yang tidak dapat dipenuhi oleh proses peradilan. Mediasi penal merupakan salah satu bentuk alternatif penyelesaian sengketa di luar pengadilan (yang biasa dikenal dengan istilah ADR atau "Alternative Dispute Resolution" atau "Apropriate Dispute Resolution"). Mediasi penal mempertemukan antara pelaku tindak pidana dengan korban, maka mediasi penal ini sering juga dikenal dengan istilah "Victim-Offender Mediation" (VOM), Tater-Opfer-Ausgleich (TOA), atau Offender-victim Agreement (OVA). ${ }^{4}$

Menghindari terjadinya hal seperti di atas maka ide Restorative Justice diimplementasikan ke dalam formulasi ketentuan peraturan perundang-undangan di indonesia terutama yang berkaitan dengan anak. Implementasi yang ada pun bukan hanya berupa perwujudan yang nyata tertulis dalam undang-undang, melainkan juga terdapat ketentuan-ketentuan yang merupakan perwujudan secara tersirat. Maka dibutuhkan modal pemahaman yang kuat tentang ide itu sendiri oleh para penegak hukum agar pemulihan (restorasi) dapat benar terjadi khususnya dalam kasus hukum pidana anak.

Restorative Justice sebenarnya memiliki posisi yang strategis sebagai suatu sarana dalam mempertahankan hak-hak anak yang berkonflik dengan hukum. Namun yang menjadi kendala adalah bagaimana Restorative Justice itu tidak dapat berjalan secara efisien bila diterapkan bukan dengan cara yang benar. Untuk dapat menerapkannya dengan benar harus dipahami terlebih dahulu bagaimana Restorative Justice tersebut diimplementasikan dalam formulasi ketentuan perundangundangan yang ada. Walaupun dalam ketentuan perundang-undangan anak itu sendiri tetap ditemukan adanya ketentuan pidana, para penegak hukum harus memahami bagaimana penerapannya dengan sebaik mungkin agar kiranya keadilan tetap ditegakkan dan hak-hak anak tetap terlindungi.

Berdasarkan latar belakang di atas, penulis menentukan sebuah bahasan penelitian yang berjudul "Implementasi Ide Restorative Justice Ke Dalam Ketentuan Peraturan PerundangUndangan Anak Di Indonesia", dengan suatu rumusan masalah sebagai berikut:

\footnotetext{
${ }^{2}$ Yoachim Agus Tridiatno, Keadilan Restoratif (Yogyakarta: Cahaya Atma Pustaka, 2015), hal.27.

${ }^{3}$ Jim Consedine, Restorative Justice: Healing the Effects of Crima, (Lyttelton: Ploughshares Publications, 1995), hal. 11.

${ }^{4}$ Barda Nawawi Arief, Mediasi Penal: Penyelesaian Perkara Pidana di Luar Pengadilan, (Semarang:

Peberbit Pustaka Magister, 2016), hal. 1-3.
} 
1) Bagaimanakah ide Restorative Justice diimplementasikan dalam formulasi ketentuan peraturan perundang-undangan anak di Indonesia?

2) Bagaimanakah penerapan ketentuan pidana pada peraturan perundang-undangan anak di Indonesia dalam perspektif Restorative Justice?

3) Bagaimanakah kebijakan formulasi terkait ide Restorative Justice dalam peraturan perundangundangan anak di Indonesia pada masa yang akan datang?

Yang bertujuan:

1) Untuk mengetahui sinkronisasi/harmonisasi formulasi ide Restorative Justice di berbagai peraturan perundang-undangan anak di Indonesia.

2) Untuk memahami penerapan ketentuan pidana pada peraturan perundang-undangan anak di Indonesia dalam mewujudkan perlindungan anak sebagai tujuan diterapkannya ide Restorative Justice.

3) Untuk memahami kebijakan formulasi terkait ide Restorative Justice dalam peraturan perundang-undangan anak di Indonesia pada masa yang akan datang

\section{METODE PENELITIAN}

Permasalahan pokok dalam penelitian ini adalah implementasi ide Restorative Justice dalam formulasi ketentuan peraturan perundang-undangan anak di Indonesia dan penerapan ketentuan pidana dalam perspektif Restorative Justice pada ketentuan peraturan perundangundangan anak di Indonesia serta kebijakan formulasi terkait ide Restorative Justice pada masa yang akan datang. Dalam mencapai sasaran penelitian ini menggunakan pendekatan yuridis normatif. Pendekatan secara yuridis normatif adalah pendekatan melalui studi kepustakaan (library research) dengan cara membaca, mengutip dan menganalisis teori-teori hukum dan peraturan perundang-undangan yang berhubungan dengan permasalahan dalam penelitian. ${ }^{5}$

Sudarto berpendapat bahwa metode yuridis dalam arti sempit ialah penggunaan metode yang hanya melihat yang logis atau anti logis, ataupun dengan cara lain yang sistematis, di dalam keseluruhan perangkat norma. Sebaliknya apabila yang dilihat itu tidak hanya hubungannya di dalam perangkat norma belaka, tetapi juga bahkan terutama dilihat pentingnya efek sosial dari pembentukan norma-norma (hukum) sehingga justru dilihat pentingnya latar belakang kemasyarakatannnya, maka metode ini tidaklah kurang yuridis pula, ialah yuridis dalam arti luas. ${ }^{6}$ Mengomentari hal tersebut, Barda Nawawi Arief berpendapat bahwa penggunaan landasan atau metode/pendekatan filosofis, komparatif dan historis di dalam memahami masalah hukum yang diteliti juga dapat dimasukkan dalam pengertian metode/pendekatan normatif (yuridis) dalam arti luas. ${ }^{7}$

Berdasarkan penjelasan di atas dapat ditegaskan bahwa pendekatan Yuridis Normatif yang dilakukan pada penelitian ini tidak hanya sebatas melihat secara logis/ sistematis dalam keseluruhan perangkat norma melainkan juga mencakup latar belakang filosofis, sosiologis, historis, komparatif.

\section{HASIL PENELITIAN DAN PEMBAHASAN}

\section{A. Implementasi ide Restorative Justice dalam formulasi ketentuan peraturan perundang- undangan anak di Indonesia}

\footnotetext{
${ }^{5}$ Soerjono Soekanto, Pengantar Penelitian Hukum, (Jakarta: Rineka Cipta, 1983), hal. 7.

${ }^{6}$ Sudarto, Hukum dan Hukum Pidana, 1981, hal. 13. Dalam Bahan Kuliah, Barda Nawawi Arief, Metode Penelitian Hukum, Semarang: Magister Ilmu Hukum UNDIP 2017, disampaikan pada tanggal 11 Agustus 2017, hal.16.

${ }^{7}$ Bahan Seminar, Barda Nawawi Arief, Metode Penelitian Hukum, Purwokerto: UNSOED, 11 - 15 September 1995.
} 
Implementasi ide Restorative Justice dalam formulasi ketentuan peraturan perundangundangan anak di indonesia dapat ditemukan baik dalam ketentuan sistem peradilan pidana anak (Undang-undang Nomor 11 Tahun 2012) maupun ketentuan perlindungan hukum terhadap anak (Undang-undang Nomor 35 Tahun 2014 jo. Undang-undang Nomor 23 Tahun 2002). Unsurunsur dari ide Restorative Justice dapat ditemukan dalam Handbook on Restorative justice programmes yang dikeluarkan oleh United Nations. Sedangkan tujuan-tujuan dapat ditemukan dalam Basic Principles On The Use Of Restoratif Justice Programmes In Criminal Matters yang dihasilkan oleh United Nations Economic and Social Council (ECOSOC).

Indonesia merupakan anggota dari United Nations (Perserikatan Bangsa-bangsa) dan tercatat sebagai member of United Nations Economic and Social Council (ECOSOC), sehingga kedua ketentuan tersebut dapat digunakan sebagai indikator dalam implementasi ide restorative justice. Basic Principles On The Use Of Restoratif Justice Programmes In Criminal Matters menyatakan bahwa Restorative Justice dapat dipahami mencakup 5 (lima) unsur: ${ }^{8}$

1) Program Restorative Justice berarti setiap program yang menggunakan proses Restorative atau bertujuan untuk mencapai hasil Restorative;

2) Hasil Restorative berarti kesepakatan dicapai sebagai hasil dari restorasi dari proses Restorative. Contoh hasil Restorative termasuk restitusi, pelayanan masyarakat dan program lain atau respon yang dirancang untuk mencapai perbaikan dari korban dan masyarakat, dan reintegrasi korban dan/atau pelaku.

3) Proses Restorative berarti setiap proses di mana korban, pelaku dan /atau orang lain atau anggota masyarakat yang terkena dampak kejahatan secara aktif berpartisipasi bersama dalam penyelesaian masalah-masalah yang timbul dari kejahatan, seringkali dengan bantuan pihak ketiga yang adil dan tidak memihak. Contoh dari proses Restorative termasuk mediasi, konferensi dan lingkaran hukuman.

4) Pihak berarti korban, pelaku, dan perorangan lainnya atau anggota masyarakat yang terkena dampak kejahatan yang mungkin terlibat dalam program Restorative Justice.

5) Fasilitator berarti pihak ketiga yang adil dan tidak memihak yang berperan untuk memfasilitasi partisipasi korban dan pelaku dalam program pertemuan.

Handbook on Restorative justice programmes yang dikeluarkan oleh United Nations memuat bahwa dijalankannya Restorative Justice mempunyai tujuan sebagai berikut: ${ }^{9}$

1) Korban yang setuju untuk terlibat dalam proses ini dapat menjalankannya dengan aman dan meghasilkan kepuasan;

2) Pelaku kejahatan memahami bahwa perbuatan mereka telah mempengaruhi korban dan orang lain, untuk kemudian bertanggung jawab atas konsekuensi dari tindakan mereka dan berkomitmen untuk membuat perbaikan/reparasi;

3) Langkah-langkah fleksibel yang disepakati oleh para pihak yang menekankan untuk memperbaiki kerusakan dilakukan dan, sedapat mungkin, juga mencegah pelanggaran; Pelanggar membuat komitmen mereka untuk memperbaiki kerusakan yang dilakukan dan berusaha untuk mengatasi faktor-faktor yang menyebabkan perilaku mereka, dan;

4) Pelaku kejahatan menghidupkan komitmen untuk memperbaiki kerusakan yang terjadi dan berusaha untuk mencari faktor-faktor yang mempengaruhi tingkah lakunya.

5) Korban dan pelaku baik memahami dinamika yang mengarah ke insiden tertentu, memperoleh hasil akhir dan reintegrasi/kembali bergabung ke dalam masyarakat.

Dalam membahas implementasi ide restorative justice dalam formulasi ketentuan peraturan perundang-undangan anak di Indonesia, ketentuan-ketentuan tersebut akan dibagi ke dalam dua klasifikasi yaitu ketentuan sistem peradilan pidana anak dan ketentuan perlindungan

\footnotetext{
${ }^{8}$ United Nation, Basic principles on the use of restorative justice programmes in criminal matters, ECOSOC Res. 2000/14, U.N. Doc. E/2000/INF/2/Add.2 at 35 (2000).

${ }^{9}$ United Nation, Handbook on Restorative justice programmes, (New York: United Nations Office on Drugs and Crime (UNODC), 2006), hlm. 9.
} 
hukum terhadap anak. Hal ini dilakukan karena secara garis besar ketentuan-ketentuan peraturan perundang-undangan anak di indonesia mengatur tentang dua hal tersebut.

\section{Implementasi ide Restorative Justice dalam formulasi ketentuan Sistem peradilan pidana anak di Indonesia}

Di dalam penjelasan umum UU No. 11 Tahun 2012 disebutkan: "UU No. 3 Tahun 1997 tentang peradilan anak dimaksudkan untuk melindungi dan mengayomi anak yang berhadapan dengan hukum agar anak dapat menyongsong masa depannya yang masih panjang serta memberi kesempatan kepada anak agar melalui pembinaan akan diperoleh jati dirinya untuk menjadi manusia yang mandiri, bertanggung jawab dan berguna bagi diri sendiri, keluarga, masyarakat, bangsa, dan negara. Namun dalam pelaksanaannya anak diposisikan sebagai objek dan perlakuan terhadap anak yang berhadapan dengan hukum cenderung merugikan anak. Selain itu, undang-undang tersebut sudah tidak sesuai lagi dengan kebutuhan hukum dalam masyarakt dan belum secara komperhensif memberikan perlindungan khusus kepada anak yang berhadapan dengan hukum".

Melakukan suatu kajian perbandingan dalam hal ini adalah dengan melihat apakah kelima unsur yang ditetapkan ECOSOC telah diformulasikan dalam ketentuan sistem peradilan pidana anak di Indonesia. Dalam hal ini dinyatakan bahwa Keadilan Restoratif merupakan suatu proses diversi berdasarkan penjelasan umum UU No. 11 Tahun 2012. Dengan kata lain apabila kelima unsur Restorative Justice di atas telah terpenuhi melalui formulasi ketentuan Diversi di Indonesia, maka hal tersebut dapat juga dikatakan telah mewakili formulasi ketentuan Restorative Justice di Indonesia dalam memenuhi kelima unsur tersebut.

Unsur pertama adalah program Restorative Justice yang berarti setiap program yang menggunakan proses Restorative atau bertujuan untuk mencapai hasil Restorative. Pasal 8 UU No. 11 Tahun 2012 yang menyatakan bahwa proses Diversi dilakukan berdasarkan pendekatan Keadilan Restoratif. Maka dalam hal ini Diversi dapat dikatakan sebagai suatu program yang bertujuan untuk mencapai hasil Restorative. Hasil Restorative dijelaskan pada unsur kedua yaitu kesepakatan dicapai sebagai hasil dari restorasi dari proses Restorative. Unsur kedua ini dapat ditemukan dalam pasal 6 (a) yaitu Diversi bertujuan mencapai perdamaian antara korban dan Anak. Dari sini dapat dilihat bahwa hasil yang diharapkan dari dijalankannya proses Diversi adalah restorasi antara korban dan Anak.

Unsur ketiga yaitu Proses Restorative yang berarti setiap proses di mana korban, pelaku dan /atau orang lain atau anggota masyarakat yang terkena dampak kejahatan secara aktif berpartisipasi bersama dalam penyelesaian masalah-masalah yang timbul dari kejahatan, seringkali dengan bantuan pihak ketiga yang adil dan tidak memihak. Hal ini dapat ditemukan dalam ketentuan pasal 6 (d) bahwa selain kedua belah pihak, Diversi juga bertujuan mendorong masyarakat untuk berpartisipasi. Secara bersamaan ketentuan tersebut juga memenuhi unsur keempat yaitu pihak, berarti korban, pelaku, dan perorangan lainnya atau anggota masyarakat yang terkena dampak kejahatan yang mungkin terlibat dalam program Restorative Justice.

Unsur kelima adalah Fasilitator yang berarti pihak ketiga yang adil dan tidak memihak yang berperan untuk memfasilitasi partisipasi korban dan pelaku dalam program pertemuan. Dalam sistem peradilan pidana anak di Indonesia unsur tersebut dapat ditemukan dalam ketentuan pasal 52 (1) dimana Ketua pengadilan wajib menetapkan Hakim atau majelis hakim untuk menangani perkara Anak paling lama 3 (tiga) hari setelah menerima berkas perkara dari Penuntut Umum. Majelis Hakim tersebut dapat disebutkan sebagai Fasilitator yang tidak memihak yang berperan untuk memfasilitasi partisipasi korban dan pelaku dalam program pertemuan yang dilaksanakan dalam hal di mediasi pengadilan negeri berdasarkan pasal 52 (4).

Konsep restorative Justice yang diimplementasikan dalam Undang-Undang No.11 Tahun 2012 Tentang Sistem Peradilan Pidana Anak mempunyai dasar yuridis. Pasal 28 ayat (2) UUD 1945 menyatakan bahwa "setiap anak berhak atas kelangsungan hidup, tumbuh dan kembang, serta berhak atas perlindungan dan diskriminasi". Hal ini dijabarkan dalam UU No.39 Tahun 1999 tentang Hak Asasi Manusia dan UU No.23 Tahun 2002 tentang Perlindungan 
Anak. ${ }^{10}$ Undang-Undang No.11 Tahun 2012 tentang Sistem Peradilan Pidana Anak dibuat sesuai dengan Konvensi Hak-Hak anak yang diratifikasi oleh pemerintah Republik Indonesia dengan keputusan Presiden Nomor 36 Tahun 1990.

Sebenarnya dalam UU No.3 Tahun 1997 tentang Pengadilan Anak sudah ada upaya pengubahan paradigma pemidanaan anak di Indonesia yang bukan lagi ditujukan untuk memberikan pembalasan (dalam pandangan retributif), akan tetapi lebih diarahkan pada proses pembinaan agar masa masa depannya menjadi lebih baik. Namun, paradigma ini dirasakan tidak cukup karena perkembangan lebih jauh dari aturan dalam Undang-Undang pengadilan anak di mana paradigma yang berkembang kemudian bukan lagi sekedar mengubah jenis pidana menjadi jenis pidana yang bersifat mendidik, tetapi seminimal mungkin memasukan anak ke dalam proses peradilan pidana. ${ }^{11}$ Oleh sebab itu, dimasukan konsep Restorative Justice ke dalam UU Sistem Peradilan Pidana Anak yang baru.

Pemahaman bahwa menjauhkan anak dari proses peradilan pidana menjadi penting karena hal ini merupakan bagian upaya perlindungan hak asasi anak sebagaimana tercantum dalam Konvensi Hak Anak yang memberikan peluang untuk dilakukannya proses pengalihan perkara (Diversi) yang dilakukan oleh Polisi dan Penuntut Umum serta pejabat lain yang berwenang menjauhkan anak dari proses peradilan.

Berdasarkan BAB I Ketentuan Umum, Pasal 1 angka (6), UU No. 11 Tahun 2012 tentang Sistem Peradilan Pidana Anak, Keadilan Restoratif adalah penyelesaian dengan melibatkan pelaku, korban, keluarga pelaku/ korban, dan pihak lain yang terkait untuk bersamasama mencari penyelesaian yang adil dengan menekankan pemulihan kembali pada keadaan semula, dan bukan pembalasan. Konsep mengenai Restorative Justice juga dapat ditemukan dalam Pasal 5, bahwa Sistem Peradilan Pidana Anak wajib mengutamakan pendekatan keadilan restoratif (ayat (1)), yang meliputi (ayat (2)):

a) Penyidikan dan penuntutan pidana anak yang dilaksanakan sesuai dengan ketentuan peraturan perundang-undangan, kecuali ditentukan lain dalam undang-undang ini;

b) Persidangan anak yang dilakukan oleh pengadilan di lingkungan peradilan umum;

c) Pembinaan, pembimbingan, pengawasan, dan/atau pendampingan selama proses pelaksanaan pidana atau tindakan dan setelah menjalani pidana atau tindakan.

Dan ditegaskan pada ayat (3) bahwa pada huruf a dan b di atas wajib diupayakan diversi. Dapat dikatakan bahwa konsep Restorative Justice merupakan sebuah terobosan hukum yang harus dan wajib digunakan dalam setiap perkara anak yang berkonflik dengan hukum, dan mempunyai peran yang besar dalam masa depan peradilan anak di Indonesia, karena Restorative Justice atau keadilan restoratif mengangkat harkat dan martabat anak seperti yang dituangkan dalam Konvensi Hak Anak. Restorative Justice mengupayakan perdamaian dalam perkara anak, menyelesaikan konflik yang melibatkan anak, sehingga menanamkan rasa tanggung jawab kepada anak serta dapat memberikan dampak positif dalam masa depan anak yang berkonflik dengan hukum.

Selain dari ketentuan-ketentuan diatas yang lebih mengarah kepada pihak pelaku/korban, dan pihak penegak hukumnya, dalam undang-undang sistem peradilan anak juga menuntut adanya peran masyarakat. Masyarakat dituntut untuk berperan dalam pelindungan Anak mulai dari pencegahan sampai dengan reintegrasi sosial Anak. Ketentuan tersebut dapat ditemukan dalam pasal 93 Undang-undang No.11 tahun 2012. Peran yang dimaksud adalah dengan cara:

a) menyampaikan laporan terjadinya pelanggaran hak Anak kepada pihak yang berwenang;

b) mengajukan usulan mengenai perumusan dan kebijakan yang berkaitan dengan Anak;

c) melakukan penelitian dan pendidikan mengenai Anak;

${ }^{10}$ Nasir Djamil, Anak Bukan Untuk Di Hukum, (Jakarta: Sinar Grafika, 2013), hal. 53.

${ }^{11}$ Ibid, hal. 134. 
d) berpartisipasi dalam penyelesaian perkara Anak melalui Diversi dan pendekatan Keadilan Restoratif;

e) berkontribusi dalam rehabilitasi dan reintegrasi sosial Anak, Anak Korban dan/atau Anak Saksi melalui organisasi kemasyarakatan;

f) melakukan pemantauan terhadap kinerja aparat penegak hukum dalam penanganan perkara Anak; atau

g) melakukan sosialisasi mengenai hak Anak serta peraturan perundang-undangan yang berkaitan dengan Anak.

Dengan kata lain, masyarakat tidak hanya tinggal dengan alasan tidak memiliki keterkaitan dengan perkara pidana anak yang sedang berlangsung. Berdasarkan keterangan di atas dapat dilihat bahwa masyarakat tetap memiliki tanggungjawab dalam perlindungan anak mulai dari pencegahan sampai dengan reintegrasi sosial anak.

\section{Implementasi ide Restorative Justice dalam ketentuan peraturan perundang-undangan tentang perlindungan anak}

Ketentuan secara tertulis mengenai Restorative Justice secara nyata tertulis memang tidak dapat ditemukan dalam undang-undang tentang perlindungan anak baik Undang-undang Nomor 23 Tahun 2002 ataupun perubahannya yaitu Undang-undang 35 Tahun 2014. Namun ketentuanketentuan yang terdapat dalam undang-undang ini bila dipahami secara lebih mendalam akan tampak terlihat bahwa mengarah kepada tujuan-tujuan dari ide restorative justice seperti halnya yang tertera dalam ketentuan Handbook on Restorative justice programmes yang dikeluarkan oleh United Nations berdasarkan tinjauan pada pertemuan United Nations Office on Drugs and Crime (UNODC) di Vienna, 30 - 31 Januari 2006.

Berdasarkan Handbook on Restorative justice programmes terkait tujuan dari ide Rerstorative Justice yang pertama adalah Korban yang setuju untuk terlibat dalam proses ini dapat menjalankannya dengan aman dan meghasilkan kepuasan. Menjadi upaya pada undangundang ini dapat terlihat dalam ketentutan Pasal 56 Undang-undang Nomor 23 Tahun 2002. Dalam pasal ini terlihat bahwa pemerintah dalam menyelenggarakan pemeliharaan dan perawatan wajib mengupayakan dan membantu anak, agar anak dapat, antara lain: berpartisipasi, bebas menyatakan pendapat dan berpikir sesuai dengan hati nurani dan agamanya; dan bebas menerima informasi lisan atau tertulis sesuai dengan tahapan usia dan perkembangan Anak. Dalam pasal ini juga dilanjutkan dengan ketentuan bahwa hal-hal tersebut dikembangkan dan disesuaikan dengan usia Anak, tingkat kemampuan Anak, dan lingkungannya agar tidak menghambat dan mengganggu perkembangan Anak.

Pemeliharaan dan perawatan yang dimaksud di atas dilakukan bagi anak terlantar, baik dalam lembaga maupun di luar lembaga (Pasal 55). Berdasarkan Pasal 1 angka (6) yang dimaksud dengan anak terlantar adalah Anak yang tidak terpenuhi kebutuhannya secara wajar, baik fisik, mental, spiritual, maupun sosial. Dengan tidak diberikannya klasifikasi mengenai pemahaman anak terlantar tersebut berarti dapat dipahami bahwa baik itu merupakan anak sebagai pelaku ataupun korban selama tidak terpenuhinya kebutuhan secara wajar, baik fisik mental, spiritual maupun sosial, maka sudah dapat disebut sebagai anak terlantar. Dengan kata lain ketentuan yang terdapat pada pada Pasal 56 berlaku bagi anak baik itu sebagai korban ataupun pelaku.

Dalam hal mencapai suatu keadaan dimana korban yang setuju untuk terlibat dalam suatu proses seperti yang dimaksud Handbook on Restorative justice programmes tentunya akan sulit apabila yang menjadi korban di sini adalah anak yang dalam keadaannya bisa dikatakan belum cakap hukum. Dalam keadaan demikian maka anak membutuhkan adanya wali yang cakap hukum. Terkait dengan hal tersebut undang-undang ini memberikan ketentuan pada Bab VII tentang Perwalian bagi anak. Selain itu diberikan pula ketentuan berdasarkan pasal 56 ayat (10) bahwa perlindungan khusus bagi anak yang berhadapan dengan hukum dilakukan melalui pemberian pendampingan Orang Tua/Wali dan orang yang dipercaya oleh Anak.

Berdasarkan Handbook on Restorative justice programmes terkait tujuan dari ide Rerstorative Justice yang kedua adalah Pelaku kejahatan memahami bahwa perbuatan mereka telah mempengaruhi korban dan orang lain, untuk kemudian bertanggung jawab atas konsekuensi 
dari tindakan mereka dan berkomitmen untuk membuat perbaikan/reparasi. Menjadi upaya pada undang-undang ini dapat terlihat dalam ketentutan Pasal 56 Undang-undang Nomor 23 Tahun 2002. Dalam pasal ini terlihat bahwa pemerintah dalam menyelenggarakan pemeliharaan dan perawatan wajib mengupayakan dan membantu anak, salah satunya adalah agar anak dapat bebas menerima informasi lisan atau tertulis sesuai dengan tahapan usia dan perkembangan Anak.

Informasi lisan atau tertulis yang menjadi hak anak di sini harus disesuaikan dengan tahapan usia serta pemahaman anak yang bersangkutan. Walaupun yang menjadi tujuan adalah pelaku kejahatan yang dalam hal ini adalah anak diharapkan mampu untuk memahami perbuatan mereka yang telah mempengaruhi orang lain, Pasal 56 dalam hal ini melindungi agar informasi yang diterima seorang anak tetap harus disesuaikan dengan tahapan usia dan perkembangan anak tersebut. Begitu juga dengan pertanggungjawaban yang diharapkan untuk membuat perbaikan/reparasi di sini tetap harus disesuaikan dengan tahapan usia dan perkembangan anak. Sehingga dalam keadaan seperti ini wali yang cakap hukum sangat dibutuhkan perannya.

Berdasarkan Handbook on Restorative justice programmes terkait tujuan dari ide Rerstorative Justice yang ketiga adalah Langkah-langkah fleksibel yang disepakati oleh para pihak yang menekankan untuk memperbaiki kerusakan dilakukan dan, sedapat mungkin, juga mencegah pelanggaran. Pasal 64 Undang-undang Nomor 35 Tahun 2014 berisi ketentuan yang mendukung tercapainya tujuan dari ide Restorative Justice tersebut.

Berdasarkan Handbook on Restorative justice programmes terkait tujuan dari ide Rerstorative Justice yang keempat adalah Pelaku kejahatan menghidupkan komitmen untuk memperbaiki kerusakan yang terjadi dan berusaha untuk mencari faktor-faktor yang mempengaruhi tingkah lakunya. Sama hal nya dengan yang dijelaskan sebelumnya, bahwa dalam mencapai tujuan ini akan sulit apabila yang menjadi pelaku di sini adalah anak yang dalam keadaannya bisa dikatakan belum cakap hukum. Dalam keadaan demikian maka anak membutuhkan adanya wali yang cakap hukum. Terkait dengan hal tersebut undang-undang ini memberikan ketentuan pada Bab VII tentang Perwalian bagi anak. Selain itu diberikan pula ketentuan berdasarkan pasal 56 ayat (10) bahwa perlindungan khusus bagi anak yang berhadapan dengan hukum dilakukan melalui pemberian pendampingan Orang Tua/Wali dan orang yang dipercaya oleh Anak.

Begitu juga dengan tujuan kelima yang berisikan Korban dan pelaku baik memahami dinamika yang mengarah ke insiden tertentu, memperoleh hasil akhir dan reintegrasi/kembali bergabung ke dalam masyarakat. Yang menjadi salah satu upaya dalam mencapai hal ini juga terletak pada Pasal 56 terutama ketentuan pada ayat (9) mengenai penghindaran dari publikasi atas identitas anak. Publikasi identitas bagi anak yang berhadapan dengan hukum dapat memberikan stigma buruk bagi anak tersebut di masyarakat yang sama sekali tidak dapat dikatakan sebagai suatu langkah perbaikan bagi anak yang berhadapan dengan hukum. Sehingga apabila identitas anak dapat terjaga dengan baik maka akan lebih memudahkan anak untuk kembali bergabung ke dalam masyarakat tanpa adanya stigma dalam dirinya.

\section{B. Penerapan ketentuan pidana dalam perspektif Restorative Justice pada ketentuan peraturan perundang-undangan anak di Indonesia}

Berdasarkan Pasal 18 Undang-undang No.11 tahun 2012 tentang Sistem Peradialan Pidana Anak, terdapat ketentuan bahwa dalam menangani perkara Anak, Anak Korban, dan/atau Anak Saksi, Pembimbing Kemasyarakatan, Pekerja Sosial Profesional dan Tenaga Kesejahteraan Sosial, Penyidik, Penuntut Umum, Hakim, dan Advokat atau pemberi bantuan hukum lainnya wajib memperhatikan kepentingan terbaik bagi Anak dan mengusahakan suasana kekeluargaan tetap terpelihara. Dilanjutkan dengan ketentuan Pasal 19 menyatakan bahwa Identitas Anak, Anak Korban, dan/atau Anak Saksi wajib dirahasiakan dalam pemberitaan di media cetak ataupun elektronik. Sedangkan 'Identitas' sebagaimana dimaksud meliputi nama 
Anak, nama Anak Korban, nama Anak Saksi, nama orang tua, alamat, wajah, dan hal lain yang dapat mengungkapkan jati diri Anak, Anak Korban, dan/atau Anak Saksi.

Walaupun terdapat ketentuan seperti dijelaskan di atas, pada kenyataannya masih banyak penyimpangan dalam praktek yang terjadi. Mengutip dari website resmi milik Mahkamah Agung (www.mahkamahagung.go.id) yang mempublikasikan putusan-putusan dari berbagai tingkat pengadilan, ditemukan beberapa penyimpngan tersebut, anatara lain:

1) Putusan Nomor 1241 K/PID.SUS/2016

$\begin{array}{ll}\text { Nama } & \text { : Firman Dwi Paksi alias AIK bin Yefrizal } \\ \text { Tempat lahir } & \text { : Semarang } \\ \text { Umur/Tanggal lahir } & : \text { 17 tahun / 23 Juni 1998 } \\ \text { Jenis Kelamin } & : \text { Laki-laki } \\ \text { Pekerjaan } & \text { : Swasta (Pengamen) } \\ \text { Ancaman Pidana } & \text { : Pasal 363 ayat (1) ke-4, 5 KUHP }\end{array}$

2) Putusan Nomor 776 K/PID.SUS/2015

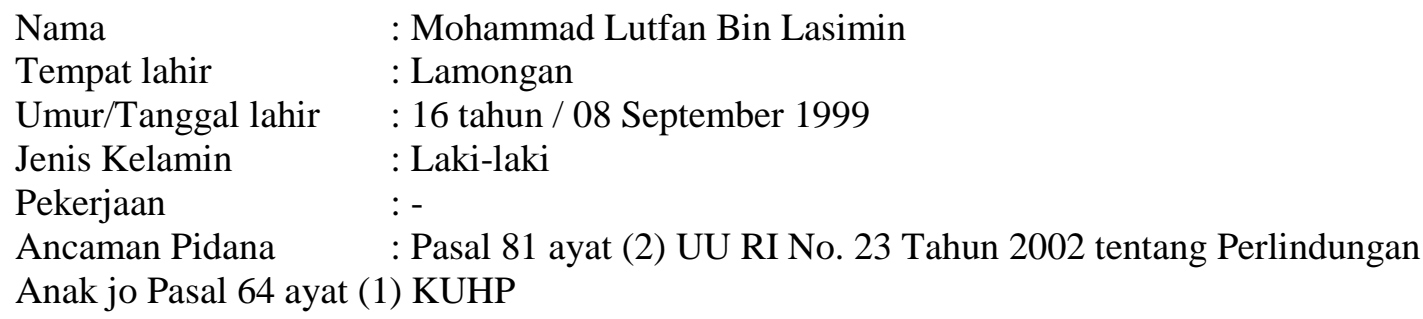

3) Putusan Nomor 774 K/PID.SUS/2015
Nama
: Terdakwa
Tempat lahir
: Lampung
Umur/Tanggal lahir
: 16 tahun / 04 Agustus 1997
Jenis Kelamin
: Laki-laki
Pekerjaan
: Belum bekerja
Ancaman Pidana : : Pasal 340 KUHP Juncto Pasal 55 ayat (1) KUHP Juncto Pasal 1
ke-3 UU RI No.11 Tahun 2012 tentang Sistem Peradilan Pidana Anak

4) Putusan Nomor 353 K/PID.SUS/2014

$\begin{array}{ll}\text { Nama } & \text { : TDW1 } \\ \text { Tempat lahir } & : \text { Palopo } \\ \text { Umur/Tanggal lahir } & : \text { 17 tahun / Oktober 1994 } \\ \text { Jenis Kelamin } & \text { : Laki-laki } \\ \text { Pekerjaan } & : \text { Pelajar SMKN } \\ \text { Nama } & \text { : TDKW2 } \\ \text { Tempat lahir } & \text { : Palopo } \\ \text { Umur/Tanggal lahir } & : \text { 16 tahun / Agustus 1995 } \\ \text { Jenis Kelamin } & \text { : Laki-laki } \\ \text { Pekerjaan } & : \text { Pelajar SMKN } \\ \text { Ancaman Pidana } & \text { : Pasal 170 Ayat (2) ke-1 KUHP }\end{array}$

Dalam kasus di atas, para terdakwa berumur belum genap 18 (delapan belas) tahun, dan berdasakan Undang-undang Nomor 11 Tahun 2012 tentang Sistem Peradilan Anak dapat dikategorikan sebagai Anak yang berhadapan dengan hukum yang dalam hal ini merupakan anak pelaku. Berdasarkan Pasal 19 undang-undang yang sama identitas Anak, Anak Korban, dan/atau Anak Saksi wajib dirahasiakan dalam pemberitaan di media cetak ataupun elektronik. Mengenai kerahasiaan identitas nama terdakwa yang merupakan anak memang disamarkan pada kasus ke-4 (empat), namun terkait penahanan yang dilakukan terhadap kedua anak tersebut dapat dikatakan sebagai suatu tindakan perampasan kemerdekaan yang tidak sejalan dengan tujuan Diversi pada Pasal 6 Undang-undang 11 Tahun 2012. Ancaman pidana yang terdapat 
dalam Pasal 170 Ayat (2) ke-1 KUHP juga hanya sebesar 5 (lima) tahun 6 (enam) bulan. Hal tersebut berarti merupakan ancaman yang dibawah 7 tahun yang berdasarkan ketentuan Pasal 7 ayat (2) Diversi wajib diupayakan. Namun hal tersebut tidak dapat disalahkan karena melihat waktu dilimpahkannya kasus ini ke pengadilan negeri adalah tahun 2012 sedangkan berdasarkan Pasal 108 menyatakan bahwa undang-undang ini baru mulai berlaku setelah 2 (dua) tahun terhitung sejak tanggal diundangkan yaitu 30 Juli 2012. Dengan kata lain undang-undang ini baru mulai berlaku pada tanggal 30 Juli 2014, dan sebelum tanggal tersebut maka yang berlaku adalah masih Undang-undang Nomor 3 Tahun 1997 tentang Pengadilan Anak.

Berbeda dengan terdakwa pada kasus pertama dan kedua yang berumur belum genap 18 (delapan belas) tahun berdasakan Undang-undang Nomor 11 Tahun 2012 tentang Sistem Peradilan Anak dapat dikategorikan sebagai Anak yang berhadapan dengan hukum yang dalam hal ini merupakan anak pelaku. Berdasarkan Pasal 19 undang-undang yang sama seharusnya identitas Anak, Anak Korban, dan/atau Anak Saksi wajib dirahasiakan dalam pemberitaan di media cetak ataupun elektronik. Namun dalam kasus ini nama Anak yang berhadapan dengan hukum secara terang-terangan dipublikasikan melalui situs web media elektronik yang dapat diakses secara bebas oleh umum. Terkait penahanan yang dilakukan terhadap anak Mohammad Lutfan, hal tersebut dapat dikatakan sebagai suatu tindakan perampasan kemerdekaan yang tidak sejalan dengan tujuan Diversi pada Pasal 6 Undang-undang 11 Tahun 2012. Walaupun demikian hal tersebut tidak dapat disalahkan karena berdasarkan ketentuan Pasal 7 ayat (2) Diversi wajib diupayakan hanya untuk tindak pidana anak yang ancamannya dibawah 7 (tujuh) tahun dan bukan merupakan pengulangan. Sedangkan dalam kasus ini tindak pidana yang dilakukan merupakan tindak pidana terkait Pasal 81 ayat (2) UU RI No. 23 Tahun 2002 tentang Perlindungan Anak jo Pasal 64 ayat (1) KUHP yang ancaman penjaranya maksimal 15 (lima belas) tahun sehingga tidak memenuhi Pasal 7 ayat (2) dengan kata lain tidak wajib diupayakannya Diversi. Selain itu ketentuan penahanan anak yang dijelaskan pada Pasal 32 ayat (2a) yang menyatakan bahwa penahanan terhadap Anak hanya dapat dilakukan dengan syarat anak telah berumur 14 (empat belas) tahun atau lebih, dalam hal ini telah terpenuhi karena anak tersebut telah berumur 16 (enam belas) tahun.

Ketentuan pidana lainnya dalam peraturan perundang-undangan anak di Indonesia dapat ditemuka dalam Undang-undang Nomor 23 Tahun 2002 tentang Perlindungan Anak serta perubahannya yang di atur dalam Undang-undang Nomor 35 Tahun 2014. Hal tersebut disatukan dalam Bab XII tentang Ketentuan Pidana yaitu mulai dari Pasal 77 sampai Pasal 90. Namun dari ketentuan pidana yang terdapat dalam Pasal 77 sampai Pasal 90 semuanya ditujukan kepada pelaku tindak pidana dengan anak sebagai korbannya. Sedangkan terkait ketentuan pidana bagi anak sebagai pelaku dalam undang-undang ini tidak terdapat ketentuan yang mengatur.

Berbicara mengenai implementasi ide restorative justice yang terdapat dalam ketentuan pidana Undang-undang Nomor 23 Tahun 2002, walaupun tidak terwujud secara gamblang implementasi tersebut dapat terlihat dalam ketentuan Pasal 78. Seperti sudah dijelaskan sebelumnya bahwa perwujudan ide restorative justice juga meliputi peran masyarakat yang dipaparkan dalam ketentuan Pasal 93 Undang-undang Nomor 11 Tahun 2012. Mengenai implementasi tersebut ternyata terdapat kaitannya dengan ketentuan pidana pada Pasal 78 Undang-undang Nomor 23 Tahun 2002.

Ketentuan Pasal 93 Undang-undang Nomor 11 Tahun 2012 menyatakan bahwa Masyarakat juga berperan serta dalam pelindungan Anak mulai dari pencegahan sampai dengan reintegrasi sosial Anak dengan cara. Sedangkan salah satu ketentuan pidana dalam Pasal 78 Undang-undang Nomor 23 Tahun 2002 meliputi setiap orang (termasuk di dalamnya adalah masyarakat) yang mengetahui dan sengaja membiarkan anak yang berhadapan dengan hukum padahal anak tersebut memerlukan pertolongan dan harus dibantu, dipidana dengan pidana penjara paling lama 5 (lima) tahun dan/atau denda paling banyak Rp. 100.000.000,- (seratus juta 
rupiah). Dengan kata lain ketentuan pidana tersebut mengharuskan masyarakat untuk berperan dalam diwujudkannya keadilan restoratif bagi anak yang berhadapan dengan hukum.

\section{Kebijakan formulasi terkait ide Restorative Justice dalam peraturan perundang-undangan anak di Indonesia pada masa yang akan datang.}

Kebijakan formulasi terkait ide Restorative Justice dalam peraturan perundangundangan anak di Indonesia pada masa yang akan datang dapat dilihat melalui formulasi Rancangan Kitab Undang-undang Hukum Pidana (RKUHP) terbaru yaitu tahun 2015. Dapat dikatakan demikian karena RKUHP 2015 merupakan ius constituendum di Indonesia yang pada dasarnya dibuat untuk menggantikan KUHP peninggalan Belanda yang berlaku sekarang. Maka RKUHP 2015 juga nantinya yang akan memayungi segala peraturan perundang-undangan pidana di Indonesia termasuk tentang anak.

RKUHP saat ini dapat dikatakan secara filosofis "berkiblat" pada restorative justice, dapat dilihat pada tujuan pemidanaan, sebagaimana ditunjukkan oleh Pasal 54 RKUHP sebagai tujuan pemidanaan, yaitu :

1) pemidanaan bertujuan :

a. mencegah dilakukannya tindak pidana dengan menegakkan norma hokum demi pengayoman masyarakat

b. memasyaratkan terpidana dengan mengadakan pembinaan sehingga menjadi orang yang baik dan berguna

c. menyelesaikan konflik yang ditimbulkan oleh tindak pidana, memulihkan keseimbangan, dan mendatangkan rasa damai dalam masyarakat; dan

d. membebaskan rasa bersalah pada terpidana

2) Pemidanaan tidak dimaksudkan untuk menderitakan dan merendahkan martabat manusia

Berdasarkan ketentuan di atas berarti tujuan sebenarnya dari pemidanaan pada RKUHP ini telah jelas, memasyaratkan dan memulihkan keseimbangan yang telah terjadi akibat adanya tindak pidana yang dilakukan di masyarakat, dan bukanlah dengan melakukan pembalasan semata agar pelaku mendapat hukuman, sebagaimana ditegaskan oleh ayat dua dari pasal 54 RKUHP.

Penjelasan dari Buku Kesatu RKUHP sendiri menyatakan bahwa RKUHP memiliki perbedaan secara filosofis dari KUHP yang lama, di mana penyusun KUHP mendasarkan sistem peradilan pidana yang berasaskan pada aliran klasik (daad strafrecht $)^{12}$ yang terlihat dari pidana - pidana pokok yang baru seperti pidana pengawasan dan pidana kerja sosial, yang akan digunakan sebagai alternative dari hukuman perampasan kemerdekaan sementara, sehingga terpidana akan dibantu membebaskan diri dari rasa bersalah, menghindari efek destruktif dari perampasan kemerdekaan sementara, dan membantu masyarakat berperan secara aktif menjalankan kehidupan sosialnya.

Pengaturan yang dengan jelas menggambarkan bahwa RKUHP bersifat restorative justice dapat dilihat dari pasal 55 RKUHP di mana terdapat pedoman pemidanaan, yang mensyaratkan hal - hal yang harus diperhatikan dalam mengambil putusan pidana. Dengan mempertimbangkan hal - hal tersebut, dan juga dengan pedoman penerapan pidana penjara dengan perumusan tunggal dan perumusan alternatif serta lain - lain ketentuan pemidanaan pada paragraf empat dan paragraf 5 RKUHP. Disyaratkan hal - hal yang dapat membebaskan terpidana dari keharusan menjalani hukuman penjara dan menjadi hukuman pokok lainnya seperti pengawasan, denda ataupun kerja sosial serta menambahkan suatu pidana tambahan.

Sebelum adanya RKUHP ini sendiri sebenarnya restorative justice sudah ada dan hidup dalan masyarakat, seperti contohnya dalam UU Sistem Peradilan Pidana Anak yang

\footnotetext{
${ }^{12}$ Penjelasan RKUHP Buku Kesatu
} 
mensyaratkan diversi dan memiliki hukuman - hukuman pidana yang tidak terbatas pada pidana penjara semata, akan tetapi juga memikirkan kebaikan anak untuk ke depannya.

Sementara jika hanya melihat pada KUHP, sangat sedikit pilihan hukuman pidana selain hukuman perampasan kemerdekaan secara sementara sebagaimana diaturkan dalam pasal $14 \mathrm{c}$ KUHP yang lama yang dapat digunakan untuk bergerak ke arah restorative justice meskipun belum maksimal. Sehingga untuk menangani pidana umum, RKUHP adalah sebuah kemajuan dalam bidang restorative justice, sehingga terdapat persamaan tujuan antara pemidanaan pidana khusus dan pidana umum di Indonesia

Melihat ketentuan-ketentuan pada buku satu, RKUHP memiliki penjelasan yang bisa dikatakan jauh lebih merinci terutama dalam hal pidana ataupun tindakan bagi anak, apabila dibandingkan dengan ketentuan-ketentuan pada peraturan perundang-undangan yang berlaku sekarang ini. Dikatakan demikian karena pada RKUHP terdapat ketentuan-ketentuan tentang anak yang sebelumnya tidak di atur dalam perundang-undangan yang sudah berlaku seperti halnya undang-undang tentang SPPA dan undang-undang tentang Perlindungan Anak. Walaupun memiliki beberapa penambahan ataupun perubahan, RKUHP juga tetap memiliki ketentuan-ketentuan yang tidak berubah dari peraturan perundang-undangan yang berlaku sekarang.

Dalam Pasal 69 (2) Undang-undang Nomor 11 Tahun 2012, terdapat ketentuan bahwa anak yang belum berusia 14 (empat belas) tahun hanya dapat dikenai tindakan, atau dengan kata lain tidak dapat dikenai pidana. Berbeda dari ketentuan tersebut, Pasal 115 (2) RKUHP menyatakan bahwa pidana bagi anak juga berlaku bagi orang yang berumur antara 12 (dua belas) sampai 18 (delapan belas) tahun. Pada dasarnya ketentuan umur anak pada kedua perundang-undangan ini adalah sama yaitu antara 12 (dua belas) sampai 18 (delapan belas) tahun, namun yang menjadi pembeda adalah ditiadakannya ketentuan batasan umur yang secara khusus diatur untuk dapat diberlakukannya pidana bagi anak.

Namun yang menjadi keunggulan dari formulasi RKUHP dalam hal ini, terdapat penjelasan lebih lanjut mengenai penentuan batasan umur tersebut. Pada Penjelasa RKUHP sendiri dijelaskan bahwa ketentuan ini mengatur tentang batas umur minimum untuk dapat dipertanggungjawabkan secara pidana bagi seorang anak yang melakukan tindak pidana. Penentuan batas umur 12 (dua belas) tahun didasarkan pada pertimbangan psikologis yaitu kematangan emosional, intelektual, dan mental anak. Seorang anak di bawah umur 12 (dua belas) tahun tidak dapat dipertanggungjawabkan secara pidana dan karena itu penyelesaian kasusnya harus didasarkan pada ketentuan peraturan perundang-undangan lainnya. Batas umur maksimum 18 (delapan belas) tahun untuk dapat diajukan ke pengadilan anak, adalah sesuai dengan umur kedewasaan anak, agar bagi mereka dapat diterapkan ketentuan mengenai anak. ${ }^{13}$

Berdasarkan ketentuan tersebut dapat terlihat bahwa ketentuan batas umur yang dilakukan berdasarkan pertimbangan psikologis yaitu kematangan emosional, intelektual, dan mental anak. Maka dapat dikatakan pula bahwa berdasarkan pertimbangan tersebut diterapkannya pidana bagi anak di luar batasan umur tersebut akan mengganggu aspek psikologis anak. Ketentuan ini sejalan dengan prinsip dari ide restorative justice karena dengan menghindari penerapan pidana yang justru mengganggu aspek psikologi anak, hal ini termasuk dalam upaya mencapai keadilan yang restoratif.

Meskipun tidak dijelaskan secara tertulis dalam RKUHP terkait restorative justice yang diwujudkan melalui Diversi seperti halnya diatur dalam undang-undang SPPA, RKUHP tetap memiliki ketentuan terkait wajibnya dilakukan Diversi dalam suatu keadaan tertentu. Hal tersebut dijelaskan dalam Pasal 117 bahwa setiap penyidik, penuntut umum, dan hakim dalam memeriksa anak wajib mengupayakan diversi. Diversi tersebut dilaksanakan dalam hal tindak pidana yang dilakukan diancam dengan pidana penjara di bawah 7 (tujuh) tahun dan bukan merupakan pengulangan tindak pidana.

${ }^{13}$ Penjelasa RUU KUHP 25 Februari 2015, hal. 192 - 193. 
Terkait tentang pengulangan (recidive) yang dapat dijadikan sebagai alasan pemberatan pidana berdasarkan Pasal 142 dan 142, hal tersebut tidak berlaku terhadap anak sebagaimana diatur dalam Pasal 119. Hal tersebut dijelaskan lebih lanjut dalam Penjelasan RKUHP terkait Pasal 119. Mengingat bahwa pengulangan tindak pidana (recidive) yang dilakukan oleh anak pada umumnya disebabkan oleh pengaruh lingkungan dan bukan karena bakat jahat dari anak itu sendiri, maka pemberatan pidana pada pengulangan tindak pidana yang dilakukan anak tidak perlu diterapkan.

Pidana yang dapat dijatuhkan terhadap anak dijelaskan pada Pasal 121 yaitu pidana pokok dan pidana tambahan. Penjelasan tentang pasal ini menyatakan bahwa ketentuan dalam pasal ini memuat jenis-jenis pidana bagi anak yang dapat dijatuhkan oleh hakim. Hakim dapat memilih pidana yang dianggap tepat sesuai dengan berat ringannya tindak pidana yang dilakukan dan sifat anak yang bersangkutan.

Penjelasan yang mengindikasikan adanya implementasi ide restorative justice dalam hal ini adalah dasar hakim dalam memilih pidana bukan hanya disesuaikan dengan berat ringannya tindak pidana yang dilakukan anak. Tetapi ditegaskan juga bahwa Hakim perlu mempertimbangkan sifat anak yang bersangkutan. Melihat kepada ketentuan pada pasal-pasal sebelumnya, sifat anak di sini dapat dikaitkan dengan Pasal 115 terkait psikologis anak yaitu kematangan emosional, intelektual, dan mental anak.

Salah satu pidana yang terdapat dalam ketentuan tersebut adalah pidana peringatan. Terkait pidana peringatan sebelumnya juga sudah diatur dalam undang-undang SPPA yaitu pada Pasal 72 yang menyatakan bahwa Pidana peringatan merupakan pidana ringan yang tidak mengakibatkan pembatasan kebebasan anak. Tidak ada ketentuan lebih lanjut mengenai bagaimana pelaksanaan dari Pidana peringatan itu sendiri.

Ketentuan yang sama persis juga terdapat dalam Pasal 124 RKUHP. Namun RKUHP dikatakan lebih rinci dengan adanya penjelasan mengenai pasal tersebut. Dijelaskan bahwa yang dimaksud dengan "pidana peringatan" adalah pemberian nasihat atau teguran kepada anak agar tidak mengulangi lagi perbuatannya dan menjauhi perbuatan yang bertentangan atau melawan hukum.

Ketentuan lain yang mengindikasikan adanya implementasi ide restorative justice adalah terkait ketentuan pidana pembinaan di luar lembaga yang terdapat dalam Pasal 127. Mengenai ketentuan pasal ini dijelaskan dalam Penjelasan RKUHP bahwa pidana pembinaan di luar lembaga dimaksudkan untuk memberikan pembinaan kepada anak, baik dalam rangka penyembuhan karena tidak atau kurang mampu bertanggung jawab pidana disebabkan sakit jiwa atau retardasi mental ataupun berupa pembinaan lainnya bagi anak yang sehat jiwanya untuk memperoleh keterampilan yang berguna bagi kehidupannya. "Penyembuhan" pada ketentuan tersebut sangat jelas mengindikasikan adanya upaya pemulihan yang pada dasarnya sejalan dengan ide restorative justice. Lebih dari itu anak juga diharapkan dapat memperoleh keterampilan yang berguna bagi kehidupan si anak.

Melihat kepada ketentuan Handbook on Restorative justice programmes yang telah dijelaskan sebelumnya terkait pemulihan yang harus diupayakan, bukan hanya bagi pihak korban ataupun pihak pelaku saja tetapi juga pemulihan keadaan di masyarakat. Upaya dalam mewujudkan hal tersebut juga terdapat dalam formulasi RKUHP yang mengatur tentang pidana pembinaan dalam lembaga pada Pasal 131. Dalam Penjelasan dinyatakan bahwa Pidana pembinaan dalam lembaga dilaksanakan baik dalam lembaga yang diselenggarakan oleh pemerintah maupun oleh swasta. Namun jika keadaan perbuatan anak membahayakan masyarakat, maka anak yang bersangkutan ditempatkan dalam Lembaga Pembinaan Khusus Anak. Lama pembinaan dalam lembaga sampai anak berumur 18 (delapan belas) tahun.

Dari ketentuan tersebut dapat disimpulkan bahwa kepentingan masyarakat juga tetap diperhatikan. Dalam hal anak dikembalikan ke masyarakat sedangkan keadaan perbuatan anak tersebut justru membahayakan masyarakat, keadilan restoratif justru tidak akan tercapai. Sehingga tetap diperhatikan dampak dari kembalinya anak ke masyarakat, apabila justru 
membahayakan maka lebih baik diberlakukan pidana pembinaan dalam lembaga sebagaimana diatur pada Pasal 131.

Sedangkan pidana pokok lainnya yang terdapat dalam Pasal 121 adalah pidana penjara yang kemudia diatur lebih lanjut dalam Pasal 133. Sama halnya dengan ketentuan dalam undang-undang SPPA, Pidana penjara terhadap anak hanya digunakan sebagai upaya terakhir, dilaksanakan di Lembaga Pembinaan Khusus Anak. Jika tindak pidana yang dilakukan anak merupakan tindak pidana yang diancam dengan pidana mati atau pidana penjara seumur hidup maka pidana yang dijatuhkan adalah pidana penjara paling lama 10 (sepuluh) tahun.

Tidak diberlakukannya pidana mati atau pidana penjara seumur hidup bagi anak dijelaskan pada Penjelasan RKUHP terkait pasal 133. Ancaman pidana mati dan pidana penjara seumur hidup tidak dapat dijatuhkan kepada anak, dengan harapan anak tersebut masih dapat dibina untuk diperbaiki baik budi pekerti maupun akhlaknya. Pidana penjara untuk anak paling lama 10 (sepuluh) tahun dianggap telah cukup untuk membina anak demi kehidupan selanjutnya. ${ }^{14}$

\section{SIMPULAN}

1. Indonesia merupakan anggota dari United Nations (Perserikatan Bangsa-bangsa) dan tercatat sebagai member of United Nations Economic and Social Council (ECOSOC), sehingga kedua ketentuan tersebut dapat digunakan sebagai indikator dalam implementasi ide restorative justice. Berdasarkan hasil penelitian ini, baik unsur-unsur maupun tujuan-tujuan dari ide restorative justice yang terdapat dalam ketentuan tersebut telah diimplementasikan ke dalam formulasi ketentuan peraturan perundang-undangan anak di Indonesia yaitu ketentuan sistem peradilan pidana anak (Undang-undang Nomor 11 Tahun 2012) maupun ketentuan perlindungan hukum terhadap anak (Undang-undang Nomor 35 Tahun 2014 jo. Undang-undang Nomor 23 Tahun 2002). Ide Restorative Justice yang ditanamkan dalam Undang-undang tersebut bukan saja diarahkan bagi pihak pelaku, pihak korban, ataupun pihak penegak hukum saja, tetapi juga ditujukan kepada masyarakat untuk berperan dalam pelindungan Anak mulai dari pencegahan sampai dengan reintegrasi sosial Anak.

2. Hukum pidana yang berfungsi untuk Policing the police salah satunya dapat terbukti dalam ketentuan pidana dalam Undang-undang No.11 tahun 2012. Ketentutan pidana dalam undangundang ini hampir keseluruhanya ditujukan pada penegak hukum yang bisa kita sebut sebagai the police. Sedangkan dalam Undang-undang Nomor 35 Tahun 2014 jo. Undang-undang Nomor 23 Tahun 2002 hampir keseluruhan ketentuan pidananya ditujukan kepada pelaku tindak pidana dengan anak sebagai korban. Ketentuan pidana yang diformulasikan ke dalam kedua undangundang tersebut sejalan dengan unsur-unsur maupun tujuan-tujuan dari ide restorative justice yang terdapat dalam ketentuan yang dikeluarkan United Nations (Perserikatan Bangsa-bangsa) dan United Nations Economic and Social Council (ECOSOC). Namun berdasarkan beberapa putusan pengadilan yang ada, masih ditemukan penyimpangan-penyimpangan dari ketentuan peraturan perundang-undangan anak yang berlaku.

3. Kebijakan formulasi terkait ide Restorative Justice dalam peraturan perundang-undangan anak di Indonesia pada masa yang akan datang dapat dilihat melalui formulasi Rancangan Kitab Undang-undang Hukum Pidana (RKUHP) terbaru yaitu tahun 2015. Dapat dikatakan demikian karena RKUHP 2015 merupakan ius constituendum di Indonesia yang pada dasarnya dibuat untuk menggantikan KUHP peninggalan Belanda yang berlaku sekarang. Dalam konteks pembaharuan hukum pidana di Indonesia juga telah mengakomodir prinsip restorative justice sebagaimana diatur dalam RKUHP 2015, dimana rumusan tentang Penanganan anak yang berhadapan dengan hukum, Jenis-jenis pidana (Strafsoort), Ukuran Pemidanaan (Strafmaat), Bentuk atau cara pemidanaan (Strafmodus), yang ditujukan bagi anak, mengandung sifat restoratif di dalamnya. Begitu juga halnya dalam undang-undang sistem peradilan pidana anak. Sehingga dapat dikatakan bahwa upaya diwujudkannya restorative justice dalam perkara anak, telah menjadi bagian dari kebijakan hukum pidana anak di Indonesia di masa yang akan datang.

\footnotetext{
${ }^{14}$ Penjelasan RUU KUHP 25 Februari 2015, hal. 195.
} 


\section{DAFTAR PUSTAKA}

Braithwaite, John. dan Pettit, Philip. 2000. Restorative Justice Philosophy to Practice. United Kingdom: Dartmouth Publishing Company

Candra, Septa. 2013. Restorative Justice: Suatu Tinjauan Terhadap Pembaharuan Hukum Pidana Di Indonesia. Jakarta: Jurnal Rechts Vinding - Media Pembinaan Hukum Nasional.

Consedine, Jim. 1995. Restorative Justice: Healing the Effects of Crime. Lyttelton: Ploughshares Publications.

Daly, Kathleen. 2000. Restorative Justice Philosophy to Practice. United Kingdom: Dartmouth Publishing Company.

Djamil, M Nasir. 2013. Anak Bukan untuk Dihukum. Jakarta: Sinar Grafika.

Ediwarman. 2006. Peradilan Anak di Persimpangan Jalan dalam Prespektif Victimology (belajar dari kasus Raju). Pekan baru: Jurnal Mahkamah Vol.18 No. 1, April 2006.

Garland, David. 1990. Punishment in Modern Society, A study in Social Theory. Oxford: Clarendon Press.

Gabbay, Zvi D. 2005. Justifying Restorative Justice: A Theoretical Justification for the Use of Restorative Justice Practices. Columbia: J. DISP. RESOL.

Groenhuijsen, Marc. 1999. Victim-Offender-Mediation: Legal and Procedural Safeguards Experiments And Legislation In Some European Jurisdictions. Belgia: Leuven, Oktober 1999.

Herlina, Apong. 2004. Restorative Justice. Jakarta: Jurnal Kriminologi Indonesia Vol.3 No.III September 2004.

Lily Pekuwali, Umbu. 2008. Memposisikan Hukum Sebagai Penyeimbang Kepentingan Masyarakat. Jakarta: Jurnal Pro Justitia, vol.26 (4) Oktober 2008.

Nawawi Arief, Barda. 2016. Mediasi Penal: Penyelesaian Perkara Pidana di Luar Pengadilan. Semarang: Peberbit Pustaka Magister.

Nawawi Arief, Barda. 2017. Metode Penelitian Hukum. Seminar disampaikan di UNSOED, Purwokerto, 11 - 15 September 1995.

Soekanto, Soerjono. Pengantar Penelitian Hukum. Jakarta: Rineka Cipta.

Sudarto. 1986. Hukum dan Hukum Pidana. Bandung: Alumni.

Tridiatno, Yoachim Agus. 2015. Keadilan Restoratif . Yogyakarta: Cahaya Atma Pustaka.

United Nation. 2000. Basic principles on the use of restorative justice programmes in criminal matters. ECOSOC Res. 2000/14, U.N. Doc. E/2000/INF/2/Add.2 at 35 (2000).

United Nation. 2006. Handbook on Restorative justice programmes. New York: United Nations Office on Drugs and Crime (UNODC).

Yunus, Yutirsa. 2013. Analisis Konsep Restorative Justice Melalui Sistem Diversi Dalam Sistem Peradilan Pidana Anak Di Indonesia. Jakarta: JURNAL Rechts Vinding - Media Pembinaan Hukum Nasional. 